\title{
GAME BERBASIS ADVENTURE SEBAGAI PENDUKUNG PEMBELAJARAN PENGENALAN KATA BAHASA INGGRIS UNTUK ANAK USIA DINI
}

\author{
Marzuki, Fandri Chandra \\ Program Studi Teknik Informatika \\ Fakultas Ilmu Komputer \\ Universitas Bandar Lampung
}

Jln. Z.A. Pagar Alam No.26 Labuhan Ratu Bandar Lampung 35142

Telp. (0721) 701463, (0721) 701979 Fax. (0721) 701467 Web.

\begin{abstract}
Abstrak
Lingkungan awal tempat anak belajar adalah pada lingkungan keluarga atau rumahnya. Dengan demikian, guru primer bagi anak adalah orang tua dan semua pihak yang terdapat dalam keluarganya. Baru kemudian setelah sang anak mendapat pendidikan formal di sekolah, lingkungan belajar anak berubah dan mendapatkan seorang guru sebagai sumber ilmu. Hal-hal awal yang dilakukan oleh anak pada usia dini adalah bermain. Bahkan dapat dikatakan bahwa kehidupan masa kecil anak dihabiskan dengan bermain. Dengan bermain, banyak hal yang dapat dipelajari oleh anak.

Ada pun yang menjadi permasalahan dalam pembuatan tugas akhir ini adalah "Bagaimanakah membangun media pembelajaran yang dapat mempermudah anak usia dini dalam menerima pembelajaran pengenalan kata dalam bahasa inggris?". Seiring dengan media pembelajaran tersebut, saat ini sering digunakan program komputer berupa permainan edukatif untuk membantu pengembangan daya kreatifitas anak. Selain itu hal ini digunakan untuk mengenalkan sejak dini kepada anak tentang teknologi komputer. Jenis Adventure game dipakai untuk mewakili rasa ingin tahu anak untuk berpetualang sebagai tokoh tertentu yang menjelajahi lingkungan sekitarnya. Jenis ini mendeskripsikan pemain sebagai seorang tokoh yang memiliki beberapa property dan kemampuan yang mampu berkembang sesuai dengan tingkatan yang telah dicapai.
\end{abstract}

Kata Kunci: anak - anak usia dini, adventure, game education

\section{PENDAHULUAN}

Lingkungan awal tempat anak belajar adalah pada lingkungan keluarga atau rumahnya. Dengan demikian, guru primer bagi anak adalah orang tua dan semua pihak yang terdapat dalam keluarganya. Baru kemudian setelah sang anak mendapat pendidikan formal di sekolah, lingkungan belajar anak berubah dan mendapatkan seorang guru sebagai sumber ilmu. Hal-hal awal yang dilakukan oleh anak pada usia dini adalah bermain. Bahkan dapat dikatakan bahwa kehidupan masa kecil anak dihabiskan dengan bermain. Dengan bermain, banyak hal yang dapat dipelajari oleh anak.

Seorang tokoh pendidikan bernama Montessori, menekankan bahwa ketika anak - anak bermain, ia akan mempelajari dan menyerap segala suatu yang terjadi di lingkungan sekitarnya. Untuk itu, perencanaan dan persiapan lingkungan belajar anak harus dirancang dengan seksama sehingga segala sesuatu dapat merupakan kesempatan belajar yang sangat menyenangkan bagi anak itu sendiri (Robby Kurniawan Budhy, 2009 : P19).

Secara umum, banyak hal yang dipelajari anak pada usia dini (3-6 tahun). Hal ini mencakup pengenalan bentuk, warna, serta benda-benda di sekitarnya. Salah satu hal yang dipelajari anak pada usia dini adalah tentang pengenalan huruf serta membentuk kata-kata dari benda yang dikenalinya. Metode yang paling efektif bagi anak dalam hal ini memang dengan menyentuh benda- 
benda yang akan dipelajarinya secara langsung. Karena itulah pada umumnya anak-anak menggunakan media pembelajaran berupa bendabenda fisik yang sesuai dengan hal yang dipelajarinya untuk perkembangan aspek psikomotoriknya.

Computer Aided Instruction (CAI) terkait langsung dengan pemanfaatan komputer dalam (kegiatan) pembelajaran didalam dan diluar kelas, baik secara individu maupun secara kelompok. CAI dapat diartikan sebagai bentuk pembelajaran yang menempatkan komputer dalam peran guru, dimana siswa berinteraksi secara langsung dengan komputer dan kontrol sepenuhnya ditangan siswa sehingga memungkinkan siswa belajar sesuai kemampuan dan memilih materi (pembelajaran) sesuai kebutuhannya (Wihardjo, 2007 : P6).

Pembelajaran bahasa inggris bagi anak anak memerlukan banyak gambar, permainan, relia, tape recorder, video ( CD / DV ), dan alat bantu lainnya ( I Made Surjana, 2006 : P36).

\subsection{Permasalahan Penelitian}

\subsubsection{Identifikasi Masalah}

Berdasarkan latar belakang di atas, maka identifikasi masalah pada penelitian ini adalah Anak - anak usia dini sulit dalam menerima pembelajaran pengenalan kata dalam bahasa inggris.

\subsubsection{Ruang Lingkup Masalah}

Agar penelitian yang dilakukan tidak terlalu menyimpang maka perlu pembatasan masalah yang difokuskan pada pembuatan game berbasis Adventure yang memuat tentang pembelajaran pengenalan kata bahasa inggris untuk anak - anak usai dini.

\subsubsection{Rumusan Masalah}

Berdasarkan latar belakang di atas, maka rumusan masalah pada penelitian ini adalah "Bagaimanakah membangun media pembelajaran yang dapat mempermudah anak usia dini dalam menerima pembelajaran pengenalan kata dalam bahasa inggris ?".

\subsection{Tujuan Penelitian dan Manfaat Penelitian}

\subsubsection{Tujuan Penelitian}

1. Mengkaji implementasi game berbasis adventure untuk pembelajaran pengenalan kata bahasa inggris.

2. Mengevaluasi kemudahan pembelajaran kata dalam bahasa inggris menggunakan game berbasis adventure.

\subsubsection{Manfaat Penelitian}

Adapun penulisan penelitian ini dapat memberikan beberapa manfaat antara lain sebagai berikut :

a. Manfaat praktis dari hasil penelitian ini adalah diharapkan agar dapat digunakan oleh anak usia dini pada saat belajar kata kata dan benda dalam bahasa inggris sehingga dapat belajar dengan menyenangkan dan tidak kesulitan dalam berbahasa inggris.

b. Manfaat teoritis dari hasil penelitian ini diharapkan dapat memberikan sumbangan bagi pengembangan teori pendidikan, khususnya untuk pembelajaran anak usia dini yang berkaitan pembelajaran pengenalan bahasa inggris.

c. Manfaat kebijakan dari hasil penelitian ini dapat digunakan sebagai bahan pertimbangan bagi lembaga pendidikan anak usia dini untuk digunakan sebagai penunjang alat bantu pembelajaran di samping metode yang sudah ada saat ini.

\section{LANDASAN TEORI}

\subsection{Game Adventure}

Game adventure merupakan program software yang mempresentasikan lingkungan tiruan yang mana pemain akan berinteraksi untuk memecahkan masalah yang ada dalam permainan tersebut ( Dilon, 2004 : P2 ).

sifat dari game petualangan (Adventure game) yaitu:

1. Alur permainan biasanya diarahkan oleh sebuah cerita narasi, selanjutnya tokoh akan bergerak sesuai alur permainan.

2. Cerita narasi juga bisa diambil dalam bentuk film, komik, novel.

3. Pemain akan mengendalikan tokoh utama.

4. Game biasanya dalam bentuk petualangan atau teka-teki, yang akan dipecahkan oleh tokoh melalui interaksi.

5. Menekankan pada penjelajahan, kemampuan berfikir dan kemampuan dalam memecahkan masalah.

6. Terdapat elemen-elemen dasar misalnya peraturan permainan, area permainan, plot, tema, tokoh, animasi, grafik, teks, suara.

\subsubsection{Definisi Game Berbasis Adventure}

Game berbasis Adventure termasuk dalam role play game dimana pemain seolah-olah 
berperan sebagai seorang tokoh dalam lingkungan game tersebut (Fatkhur Rozi, 2009 : P26).

Cerita mempunyai peran penting dalam alur game yang akan membawa sang tokoh ke arah permasalahan. Selanjutnya, player yang berperan sebagai tokoh dalam game akan melakukan interaksi untuk memecahkan masalah. Kemudian tokoh akan bertemu dengan NPC (Non Playable Charracters) yang akan berinteraksi dengan tokoh.

Lebih lanjut menyebutkan terdapat beberapa sifat dari game petualangan (Adventure game) yakni:

1. Alur permainan biasanya diarahkan oleh sebuah cerita narasi, selanjutnya tokoh akan bergerak sesuai alur permainan.

2. Cerita narasi juga bisa diambil dalam bentuk film, komik, novel.

3. Pemain akan mengendalikan tokoh utama

4. Game biasanya dalam bentuk petualangan atau teka-teki, yang akan dipecahkan oleh tokoh melalui interaksi.

5. Menekankan pada penjelajahan, kemampuan berfikir, dan kemampuan dalam memecahkan masalah.

6. Terdapat elemen-elemen dasar misalnya peraturan permainan, area permainan, plot, tema, tokoh, animasi, grafik, teks, suara.

Menurut (R. D. Duke, 1980), sebagaimana dalam Wachowicz, et al, terdapat 11 elemen game yang perlu diperhatikan sebagai dasar dalam membuat game yang baik, yaitu:

1. Format: Mendefinisikan struktur dari game. Sebuah game terdiri dari beberapa level, dan setiap level tersebut memiliki fungsinya masing-masing.

2. Rules: Di dalam sebuah game, harus terdapat perjanjian atau peraturan yang tidak dapat dirubah atau dipengaruhi oleh pemain. Oleh karena itu, dalam memainkan suatu game, pemain harus patuh dan bermain sesuai aturan yang berlaku.

3. Policy: Policy atau kebijaksanaan dapat didefinisikan sebagai aturan yang bisa dirubah atau dipengaruhi oleh pemain. Dengan adanya elemen ini, maka pemain akan dapat menggunakan dan mengembangkan strategi dalam bermain game sesuai kemampuan dirinya.
4. Scenario: Merupakan alur cerita yang digunakan sebagai kerangka atau acuan dalam bermain game.

5. Events: Adalah suatu kejadian yang menjadi tantangan sekaligus menambah keceriaan dalam bermain game. Contoh event dalam game diantaranya adalah berupa konflik, dan kompetisi.

6. Roles: Sebuah gambaran dari fungsi dan aktifitas yang dapat dibagi antar pemain dalam bermain game. Role ini tidak terbatas pada satu pemain saja. Menggunakan dua pemain atau lebih dalam role yang sama, akan memberikan keuntungan tersendiri, karena mereka bisa saling belajar dari keberhasilan dan kesalahan masing-masing pemain.

7. Decisions: Decisions merupakan suatu keputusan yang harus diambil oleh si pemain di dalam bermain game. Mengambil keputusan yang salah terhadap suatu kejadian dalam bermain game, akan dapat menjadi pelajaran yang penting bagi pemain, sehingga kesalahan tersebut tidak akan terulang lagi nantinya. Bagaimanapun juga, jika pemain terlalu banyak melakukan kesalahan, kemudian tidak dapat bertanding kembali dengan pemain lain, maka ketertarikannya terhadap suatu game akan menjadi mudah hilang. Oleh karena itu, "To keep players motivated possibilities to undo or make up for a mistake are necessary." Dikutip dari pernyataan Versteegh pada paper Wachowicz, et al.

8. Levels: Sebuah game perlu memiliki level tingkat kesulitan agar game tersebut lebih menarik dan menantang, serta dapat digunakan oleh masyarakat luas. Level easy memberikan tantangan bagi para pemain pemula (beginner), sedangkan level difficult dikhususkan bagi para pemain yang mahir dan sudah berpengalaman (expert).

9. Score Model: Merupakan instrumen yang digunakan untuk menghitung, mendata, dan menampilkan hasil dari permainan yang dimainkan. Score Model ini menjadi suatu alat yang sangat penting agar game menjadi lebih menarik.

10. Indicators: Indicators memberikan pemain suatu isyarat (hints) terhadap 
raihan atau pencapaian yang telah mereka lakukan. Elemen ini sangat penting untuk menjaga agar pemain bisa selalu termotivasi dan fokus dalam bermain.

11. Symbols: Bentuk visual dari simbolisasi element, aktivitas, dan keputusan. Pemilihan simbol yang tepat akan membantu pemain dalam memahami dan bermain game.

\subsubsection{Pembelajaran Dengan Game Komputer}

Dalam perkembangannya, pemanfaatan game di bidang pendidikan mengalami perkembangan yang signifikan. Semenjak game edukasi berkembang, teori pembelajaran memperoleh inspirasi baru dengan mempertimbangkan game edukasi sebagai salah satu model pembelajaran. Dalam penelitiannya menyatakan bahwa ternyata $84 \%$ siswa sebagai responden penelitiannya, tertarik untuk mempelajari lebih lanjut tentang kartu kredit dan penggunaanya setelah mereka memainkan elearning game CreditSafeC.

Selanjutnya, juga menyatakan bahwa game edukasi berbasis petualangan (adventure game) yang berjudul Electro Adventure yang ia kembangkan, mendapat respon positif dan sukses sebagai game pembelajaran sains. Dari sini dapat ditegaskan bahwa e-learning game juga dapat dipertimbangkan sebagai salah satu media dalam kegiatan pembelajaran ( Henry, 2005 : P7 - P9).

\subsubsection{Pembelajaran Kata Bahasa Inggris Pada Anak Usia Dini}

Secara umum, banyak hal yang dipelajari anak pada usia dini (3-6 tahun). Hal ini mencakup pengenalan bentuk, warna, serta benda-benda di sekitarnya. Salah satu hal yang dipelajari anak pada usia dini adalah tentang pengenalan huruf serta membentuk kata-kata dari benda yang dikenalinya. Metode yang paling efektif bagi anak dalam hal ini memang dengan menyentuh bendabenda yang akan dipelajarinya secara langsung. Karena itulah pada umumnya anak-anak menggunakan media pembelajaran berupa bendabenda fisik yang sesuai dengan hal yang dipelajarinya untuk perkembangan aspek psikomotoriknya ( Robby Kurniawan Budhi, 2009 : P29).

\subsubsection{Adobe Flash Professional CS5}

Flash adalah aplikasi yang sangat kaya sehingga menarik bagi designer maupun developer multimedia. Para designer sangat menyukai aplikasi ini karena kemudahannya dalam menghasilkan animasi, sedangkan para developer menikmati perlengkapannya untuk membuat aplikasi-aplikasi hebat yang ada pada Flash. Flash merupakan standar professional untuk menghasilkan web experience yang bercita-rasa tinggi ( Madcoms, 2010 : P2 ).

2.2.6 Konsep Dasar Flash

Dalam membuat sebuah aplikasi menggunakan Macromedia Flash, terdapat beberapa konsep dasar yang perlu untuk dipahami terlebih dahulu. Konsep dasar tersebut meliputi animasi, movie, objek, teks, sound dan simbol.

\section{Objek}

Flash menyediakan tool untuk membuat objek sederhana seperti garis, lingkaran, persegi empat.

2. Teks

Pada toolbox disediakan fasilitas untuk menulis teks. Flash teks dikategorikan dalam tiga jenis yaitu teks statis label, teks dinamis, dan teks input.

3. Simbol

Dalam Macromedia Flash ada beberapa simbol yang harus diketahui yaitu movie clip, button, dan graphic. Masing-masing simbol mempunyai fungsi tersendiri.

\section{Sound}

Format sound yang dapat pergunakan dalam Flash dapat bermacam-macam seperti WAV, MP3. Sound dapat mengimpor dari luar tetapi untuk sound-sound tertentu telah disediakan di dalam program Flash.

\section{Animasi}

Animasi adalah proses penciptaan efek gerak atau efek perubahan bentuk yang terjadi selama beberapa waktu. Animasi bisa berupa gerak sebuah objek dari tempat yang satu ke tempat yang lain, perubahaan warna, atau perubahan bentuk.

6. Movie

Dalam membuat animasi, maka seseorang akan mengatur jalan cerita dari animasi tersebut, membuat beberapa objek dan merangkainya menjadi suatu bagian yang bermakna tertentu. Suatu movie terkadang terdiri dari beberapa animasi yang biasa disebut movie clip. 


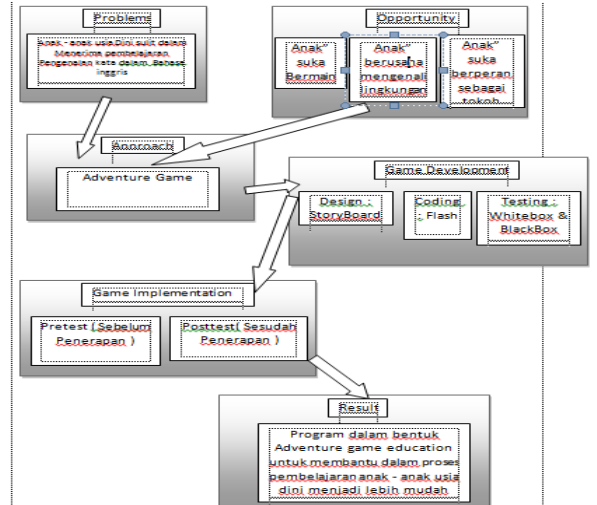

Gambar 2.1 Kerangka Pemikiran

\section{Perancangan dan Implementasi}

\subsection{Analisa Kebutuhan}

Dalam pembuatan suatu program aplikasi dibutuhkan adanya suatu analisis yang tepat tentang hal-hal yang dibutuhkan, setelah sebelumnya dilakukan proses perencanaan sehingga didapat suatu program aplikasi yang sesuai dengan kebutuhan. Setelah proses analisis dilakukan dengan benar, maka dapat diketahui kebutuhan sistem dengan tepat.

\subsubsection{Kebutuhan Software}

Dalam penelitian ini, pendekatan yang dilakukan adalah dengan penggunaan game sebagai media pembelajaran. Untuk membuat game tersebut menarik, maka konsep yang digunakan adalah dengan animasi. Untuk itu, digunakanlah Adobe Flash CS3 Professional sebagai software pembangun aplikasi game pembelajaran ini.

Program Adobe Flash CS5 Professional merupakan program yang paling fleksibel untuk membuat animasi sehingga banyak yang menggunakan program tersebut. Fungsi Adobe Flash CS5 Professional adalah membuat animasi, baik animasi interaktif maupun non interaktif. Adobe Flash CS5 Professional biasanya digunakan untuk membuat animasi web yang akan ditampilkan dalam sebuah situs internet, pembuatan animasi-animasi film, animasi iklan dan lain-lain. Adobe Flash CS5 Professional juga membutuhkan program-program lain, seperti: Macromedia Dreamweaver, Frontpage, Adobe Photoshop, CorelDraw dan lain-lain, yang digunakan untuk menghasilkan sebuah desain yang menarik.
Untuk itulah perlu juga dianalisis mengenai kebutuhan software yang digunakan, yaitu dalam hal ini Adobe Flash CS5 Professional serta kebutuhan hardware yang harus tersedia untuk dapat menggunakan aplikasi tersebut. Sesuai dengan kebutuhan minimum yang dicantumkan pada paket instalasi software Adobe Flash CS5 Professional, maka kebutuhan sistem minimum adalah sebagai berikut :

\begin{tabular}{|c|c|}
\hline Kebutuhan & Keterangan \\
\hline System Operasi & $\begin{array}{c}\text { Windows } 98 \text { SE, } \\
\text { 2000, XP atau } \\
\text { Sesudahnya } \\
\end{array}$ \\
\hline Prosesor & $\begin{array}{c}\text { Intel Pentium III } \\
\text { 600Mhz atau lebih } \\
\text { tinggi }\end{array}$ \\
\hline memory & $\begin{array}{c}128 \mathrm{Mb}( \\
\text { Direkomendasikan } \\
256 \mathrm{Mb})\end{array}$ \\
\hline Ruang Harddisk & $260 \mathrm{Mb}$ \\
\hline
\end{tabular}

\subsection{Perancangan Penelitian}

\subsubsection{Perancangan Storyboard}

\section{Setting}

Setting awal dari permainan ini adalah sebuah desa bernama desa angin. Selanjutnya, cerita pendahuluan berlanjut ke daerah padang pasir dan daerah desa air. Setting selanjutnya adalah berbagai tempat di daerah desa air, misalnya di pasar desa air, istana desa air, dan berbagai tempar di daerah desa air.

2. Tokoh

Ada beberapa tokoh dalam permainan ini yakni :

a. Hiroshi, sebagai tokoh utama dalam cerita. Seorang anak petani lulusan SD yang tidak bisa melanjutkan ke SMP karena biaya. Ia harus membantu orang tuanya untuk memenuhi kebutuhan hidup.

b. Ibu, muncul dari cerita awal, ibu dari Hiroshi. c. Ayah, muncul dari cerita awal, ayah dari Hiroshi.

d. Nagasaki, muncul dari cerita awal, adik laki laki dari Hiroshi.

e. Soha, muncul dari cerita awal, adik perempuan dari Hiroshi.

f. Nelayan 1, nelayan di desa air, yang akan membantu Hiroshi untuk kembali ke desa angin. g. Nelayan 2, nelayan di desa air, yang akan membantu Hiroshi untuk kembali ke desa angin. 
h. Raja air, raja di daerah desa air, yang akan membantu Hiroshi untuk kembali ke desa angin.

i. Penduduk local, warga desa air yang akan menunjukan jalan pulang ke desa angin.

\subsubsection{Perancangan Background}

Pada permainan ini background berawal dari desa angin.

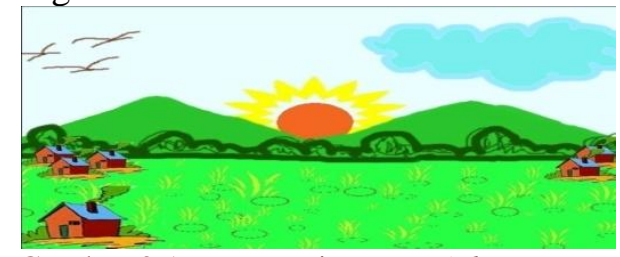

Gambar 3.1 Desa angin game Adventures In The World Of Words

Selanjutnya, menuju padang gurun.

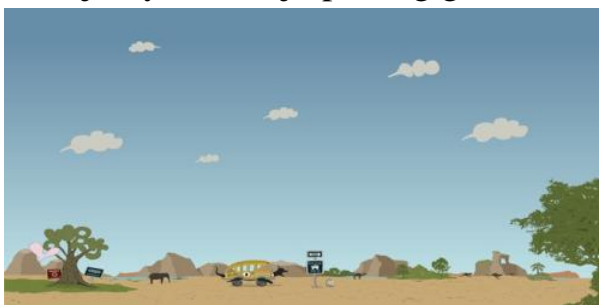

Gambar 3.2 Padang gurun game Adventures In The World Of Words

Selanjutnya, perbatasan desa air.

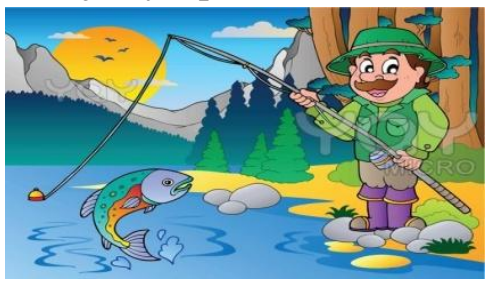

Gambar 3.3 Perbatasan desa air game Adventures In The World Of Words

Selanjutnya, pasar desa air.

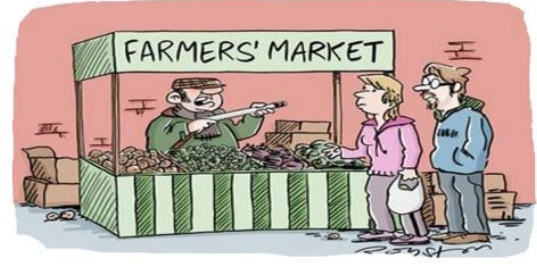

Gambar 3.4 Pasar desa air game Adventures In The World Of Words

Selanjutnya, perkampungan desa air.

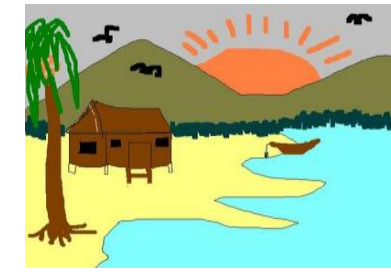

\section{Gambar 3.5 Perkampungan desa air Adventures In The World Of Words}

Selanjutnya, Istana desa air.

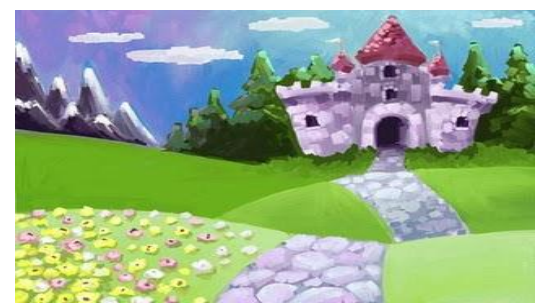

\section{Gambar 3.6 istana desa air Adventures In The World Of Words}

\subsubsection{Desain Aplikasi}

Alur permainan dalam Adventures In The World Of Words

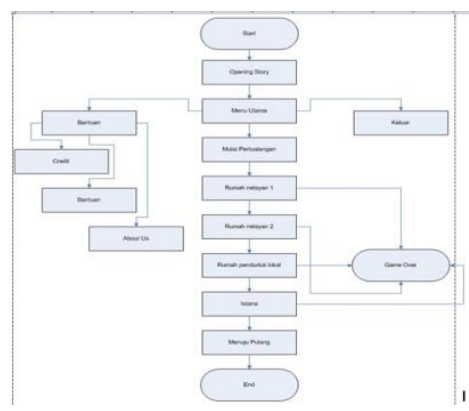

Gambar 3.16 Alur utama game Adventures In The World Of Words

\subsection{Pembahasan}

Setelah melalui tahapan analisis kebutuhan sistem, perancangan sistem, serta pembuatan storyboard selanjutnya game berbasis petualangan diimplementasikan ke dalam komponenkomponen source code, script, executable dan sebagainya. Untuk implementasi game ini, software yang digunakan adalah Macromedia Flash CS3 Professional. Hasil implementasi selanjutnya akan dievaluasi melalui tahapan pengujian (testing). Adapun hasil implementasi dari perancangan game berbasis pertualangan sebagai pendukung pembelajaran pengenalan kata 
Bahasa Inggris untuk anak usia dini adalah sebagai berikut:

\subsubsection{Halaman Intro}

Halaman Intro dari game berbasis pertualangan sebagai pendukung pembelajaran pengenalan kata Bahasa Inggris untuk anak usia dini, berupa tombol skip untuk melewati intro langsung menuju ke menu utama.

Dalam script tersebut, apabila tombol skip ditekan, maka akan langsung menuju ke menu utama.

1. Hasil tampilan halaman pembuka

Halaman pembuka yang berisi animasi teks Fan Production Mempersembahkan

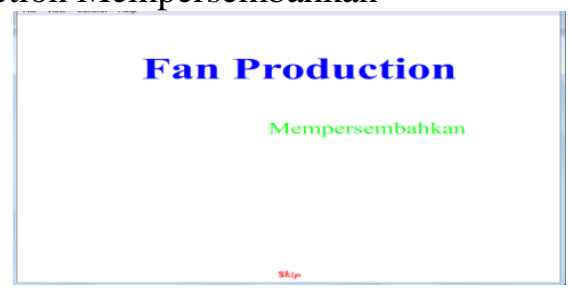

Gambar 4.1 Halaman pembuka

2. Tampilan halaman perkampungan desa angin waktu siang hari

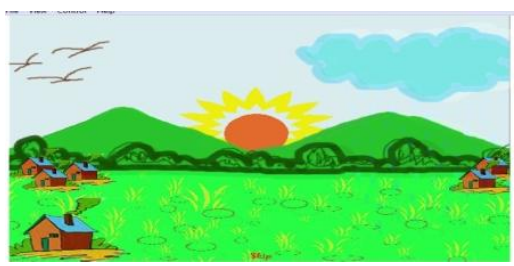

Gambar 4.2 Desa angin

3. Tampilan halaman perkampungan desa angin waktu bencana datang

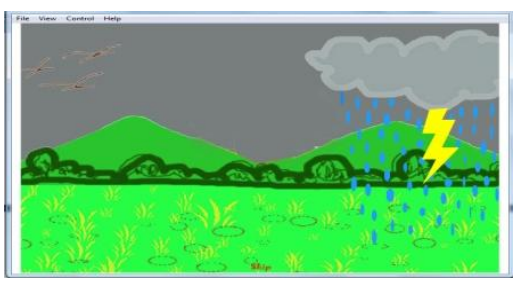

Gambar 4.3 Bencana di desa angin

4. Tampilan halaman perkampungan desa angin setelah terkena bencana

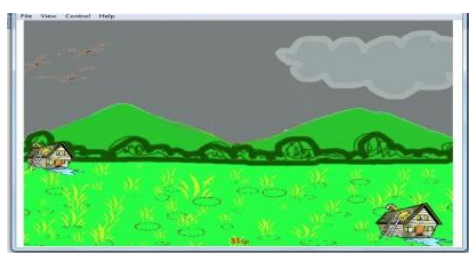

Gambar 4.4 Desa angin setelah terkena bencana

5. Tampilan halaman percakapan Hiroshi dan ibu

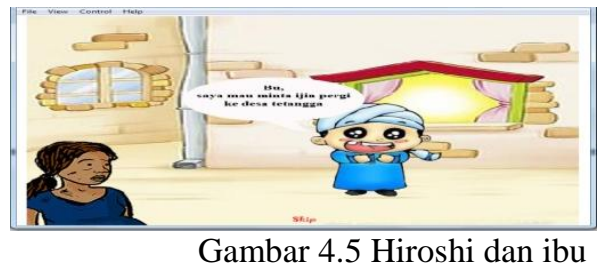

6. Tampilan halaman percakapan Hiroshi, ayah, dan adik - adiknya

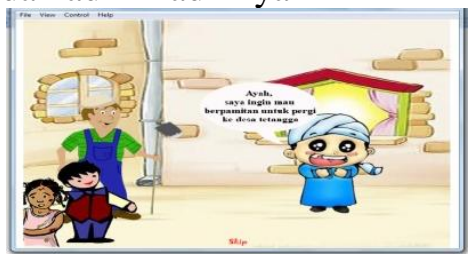

Gambar 4.6 Hiroshi, ayah, dan adik - adiknya

7. Tampilan halaman padang gurun

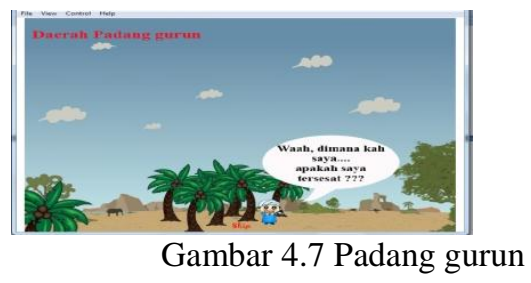

8. Tampilan halaman percakapan Hiroshi, nelayan 1 , dan nelayan 2

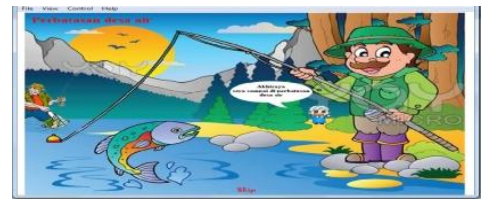

Gambar 4.8 Hiroshi, nelayan 1, dan nelayan 2

4.1.2 Halaman menu utama

Halaman menu utama dari game berbasis pertualangan sebagai pendukung pembelajaran pengenalan kata Bahasa Inggris untuk anak usia dini, berupa tombol start, help, dan quit.

1. Hasil tampilan halaman menu utama

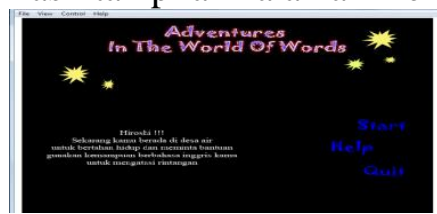

Gambar 4.9 Menu utama

4.1.3 Halaman menu start level 1

Halaman menu start level 1 dari game berbasis pertualangan sebagai pendukung 
pembelajaran pengenalan kata Bahasa Inggris untuk anak usia dini, berupa tombol start dan quit.

Hasil tampilan halaman menu start level 1

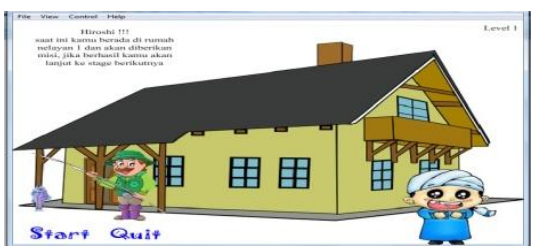

Gambar 4.10 Menu start level 1

Halaman menu help

Halaman menu help dari game berbasis pertualangan sebagai pendukung pembelajaran pengenalan kata Bahasa Inggris untuk anak usia dini, berupa tombol menu, About Us, Credit, Help, dan quit.

1. Hasil tampilan halaman menu help

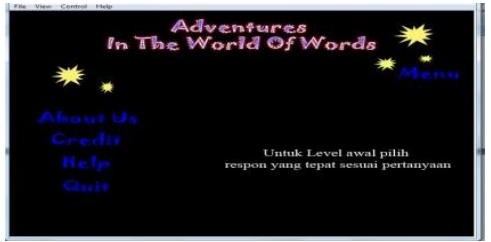

Gambar 4.11 Menu Help

Halaman menu About Us

Halaman menu About Us dari game berbasis pertualangan sebagai pendukung pembelajaran pengenalan kata Bahasa Inggris untuk anak usia dini, berupa tombol menu, About Us, Credit, Help, dan quit.

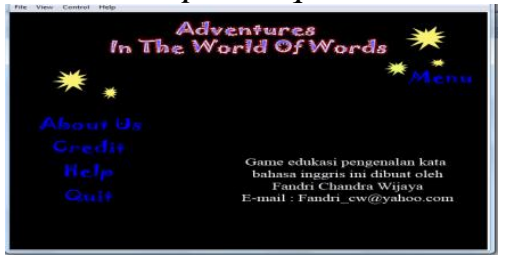

Gambar 4.12 Menu About Us

Halaman menu credit

Halaman menu credit dari game berbasis pertualangan sebagai pendukung pembelajaran pengenalan kata Bahasa Inggris untuk anak usia dini, berupa tombol menu, About Us, Credit, Help, dan quit.

1. Hasil tampilan halaman menu credit

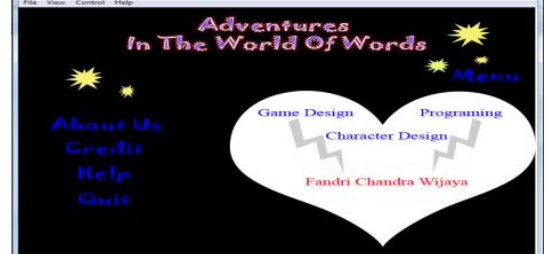

Gambar 4.13 Menu credit

\subsubsection{Halaman soal level 1}

Halaman soal level 1 dari game berbasis pertualangan sebagai pendukung pembelajaran pengenalan kata Bahasa Inggris untuk anak usia dini, berupa tombol respon pilihan jawaban.

1. Hasil tampilan menu soal level 1

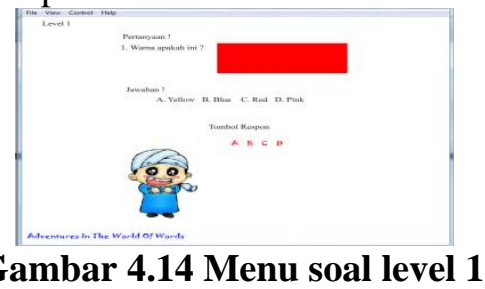

Halaman hasil level 1

Halaman hasil level 1 dari game berbasis pertualangan sebagai pendukung pembelajaran pengenalan kata Bahasa Inggris untuk anak usia dini, berisi teks nilai dan tombol next. Pada halaman ini terdapat sistem yang menganalisa hasil dan menentukan level berikutnya atau game over yang ditaruh pada tombol next.

1. Hasil tampilan menu hasil level 1

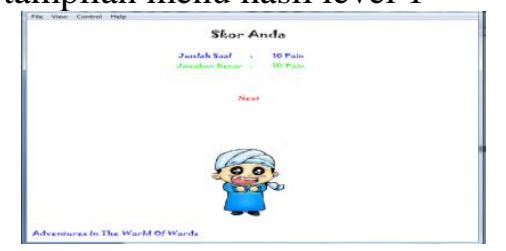

\section{Gambar 4.15 Menu hasil level 1}

Halaman start level 2

Halaman menu start level 2 dari game berbasis pertualangan sebagai pendukung pembelajaran pengenalan kata Bahasa Inggris untuk anak usia dini, berupa tombol start dan quit.

1. Hasil tampilan halaman menu start level 2 


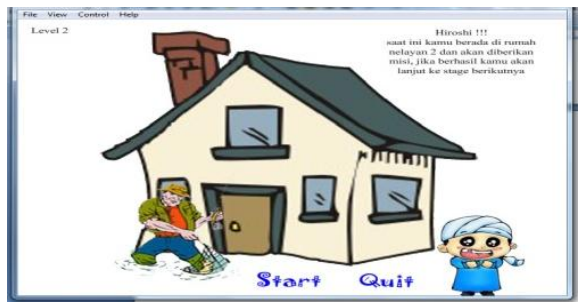

Gambar 4.16 Menu start level 2

Halaman soal level 2

Halaman soal level 2 dari game berbasis pertualangan sebagai pendukung pembelajaran pengenalan kata Bahasa Inggris untuk anak usia dini, berupa tombol respon pilihan jawaban.

1. Hasil tampilan menu soal level 2

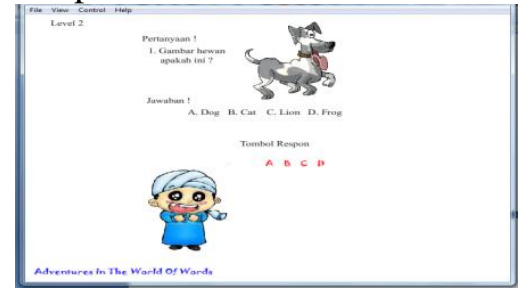

\section{Gambar 4.17 Menu soal level 2}

Halaman hasil level 2

Halaman hasil level 2 dari game berbasis pertualangan sebagai pendukung pembelajaran pengenalan kata Bahasa Inggris untuk anak usia dini, berisi teks nilai dan tombol next. Pada halaman ini terdapat sistem yang menganalisa hasil dan menentukan level berikutnya atau game over yang ditaruh pada tombol next.

1. Hasil tampilan menu hasil level 2

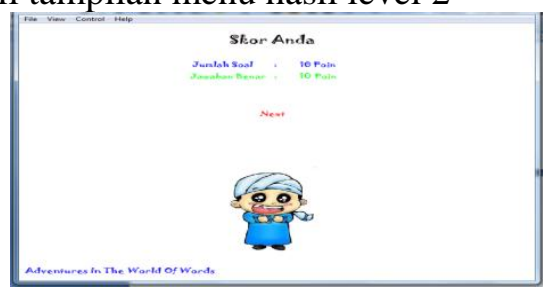

Gambar 4.18 Menu hasil level 2

Halaman start level 3

Halaman menu start level 3 dari game berbasis pertualangan sebagai pendukung pembelajaran pengenalan kata Bahasa Inggris untuk anak usia dini, berupa tombol start dan quit.

1. Hasil tampilan halaman menu start level 3

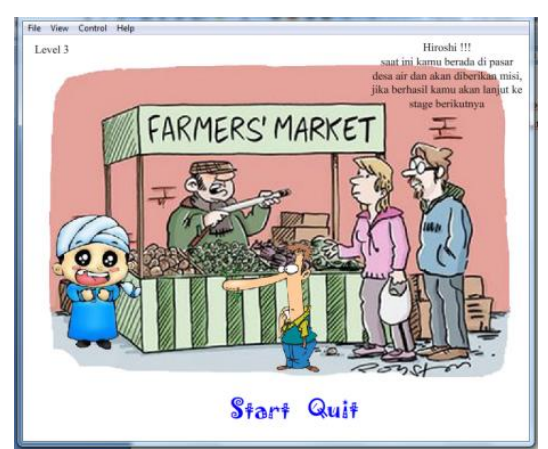

Gambar 4.19 Menu start level 3

Halaman soal level 3

Halaman soal level 3 dari game berbasis pertualangan sebagai pendukung pembelajaran pengenalan kata Bahasa Inggris untuk anak usia dini, berupa tombol respon pilihan jawaban.

1. Hasil tampilan menu soal level 3

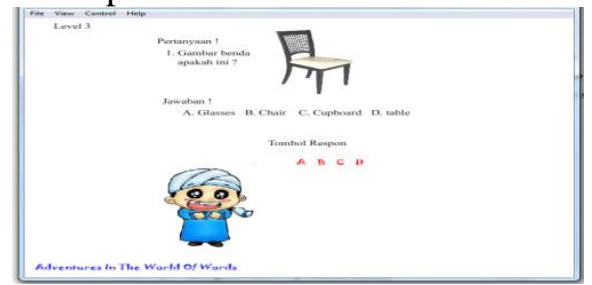

Gambar 4.19 Menu soal level 3

Halaman hasil level 3

Halaman hasil level 3 dari game berbasis pertualangan sebagai pendukung pembelajaran pengenalan kata Bahasa Inggris untuk anak usia dini, berisi teks nilai dan tombol next. Pada halaman ini terdapat sistem yang menganalisa hasil dan menentukan level berikutnya atau game over yang ditaruh pada tombol next.

1. Hasil tampilan menu hasil level 3

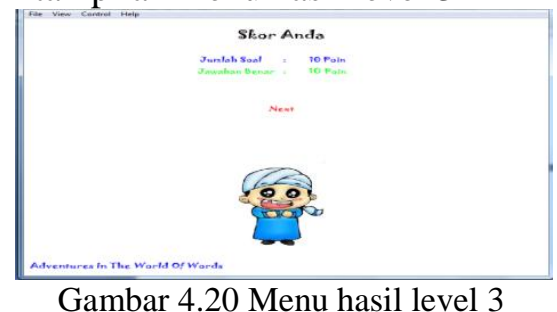

Halaman start level 4

Halaman menu start level 4 dari game berbasis pertualangan sebagai pendukung pembelajaran pengenalan kata Bahasa Inggris untuk anak usia dini, berupa tombol start dan quit.

1. Hasil tampilan halaman menu start level 4 


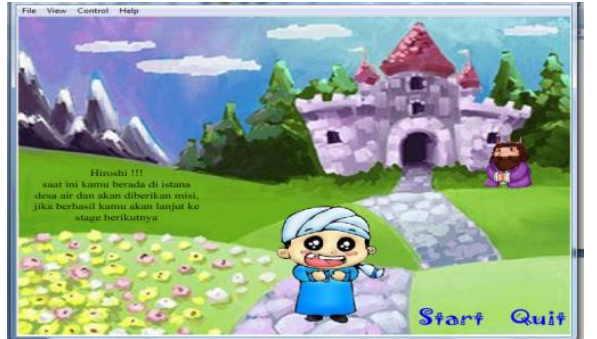

Gambar 4.21 Menu start level 4

\section{Halaman soal level 4}

Halaman soal level 3 dari game berbasis pertualangan sebagai pendukung pembelajaran pengenalan kata Bahasa Inggris untuk anak usia dini, berupa tombol respon pilihan jawaban.

1. Hasil tampilan menu soal level 4

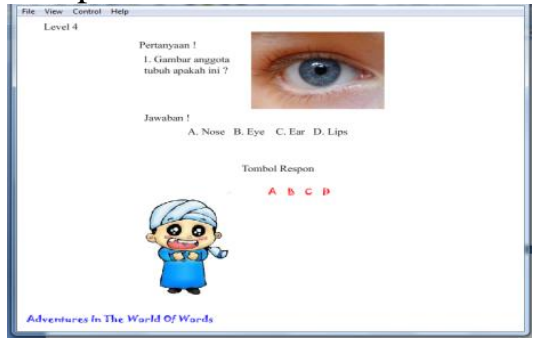

Gambar 4.22 Menu soal level 4

Halaman hasil soal level 4

Halaman hasil level 4 dari game berbasis pertualangan sebagai pendukung pembelajaran pengenalan kata Bahasa Inggris untuk anak usia dini, berisi teks nilai dan tombol next. Pada halaman ini terdapat sistem yang menganalisa hasil dan menentukan level berikutnya atau game over yang ditaruh pada tombol next.

1. Hasil tampilan menu hasil level 4

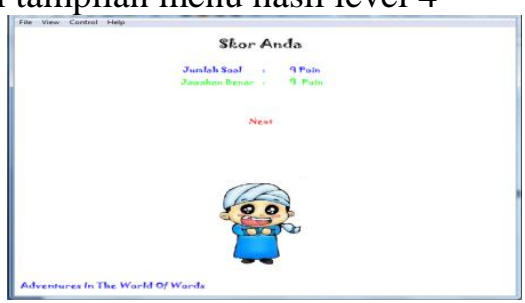

\section{Gambar 4.23 Menu hasil level 4}

Halaman reward

Halaman reward dari game berbasis pertualangan sebagai pendukung pembelajaran pengenalan kata Bahasa Inggris untuk anak usia dini, berupa tombol next dan quit.

Adapun script yang ada di halaman ini adalah :

1. Script tombol next

on(release) \{
2. Hasil tampilan halaman reward

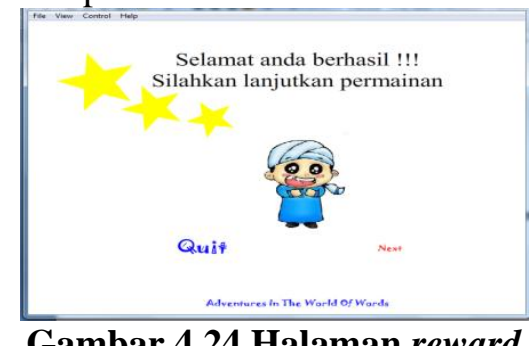

Halaman punishment

Halaman punishment dari game berbasis pertualangan sebagai pendukung pembelajaran pengenalan kata Bahasa Inggris untuk anak usia dini, berupa tombol next dan try again

\section{Hasil tampilan halaman punishment}

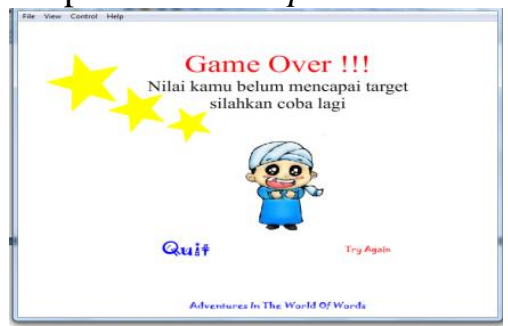

\section{Gambar 4.25 Halaman punishment}

\section{Halaman ending}

Halaman ending dari game berbasis pertualangan sebagai pendukung pembelajaran pengenalan kata Bahasa Inggris untuk anak usia dini, berupa tombol skip untuk melewati intro langsung menuju ke menu utama.

\section{Hasil tampilan ending}

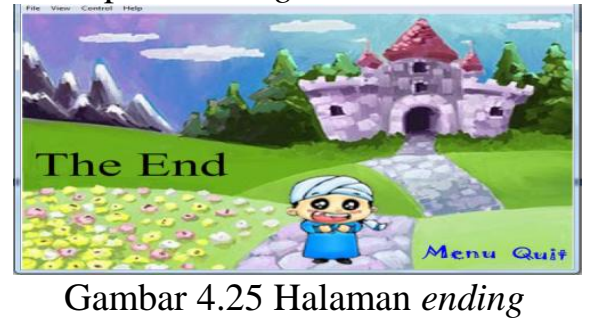

\section{KESIMPULAN DAN SARAN}

\subsection{Kesimpulan}

Dari hasil penelitian yang dilakukan mulai dari tahap perancangan hingga pengujian terhadap aplikasi game berbasis adventure sebagai pendukung pembelajaran pengenalan kata bahasa inggris untuk anak usia dini, maka disimpulkan bahwa : 
1. Dengan dirancang dan diimplementasikannya hasil rancangan tersebut ke dalam bentuk game maka proses pembelajaran pengenalan kata bahasa inggris untuk anak usia dini akan lebih mudah dimengerti oleh anak - anak.

2. Aplikasi game ini adalah sebuah alat bantu, jadi dengan adanya aplikasi game tersebut maka akan mempermudah dalam pembelajaran pengenalan kata bahasa inggris.

\subsection{Saran}

Pembelajaran dengan menggunakan game merupakan suatu model pembelajaran yang sangat layak untuk dikembangkan. Adapun penelitian serta pengembangan yang dapat dilaksanakan selanjutnya antara lain :

1. Pengembangan game dengan cerita dan tokoh yang lebih menarik, serta memasukkan materi sesuai dengan kurikulum.

2. Perlu adanya pengembangan game pembelajaran untuk mata pelajaran lain dan juga pengembangan game dengan aplikasi 3 dimensi.

\section{DAFTAR PUSTAKA}

[1] Halff. M. Henry, 2005, Adventure Game for Science Education: Generative

[2] Methods in Explanatory Environments. Halff Resources, San Antonio, USA

[4] Dillon, Teressa, 2005, Adventure Game for Learning and Story Tellin. Future Lab, UK

[5] Budhi, Kurniawan, Robby, 2009, Pengenalan Huruf Hingga Pembentukan Kata Bagi Anak Usia Dini Menggunakan Game Rpg-Adventure Dengan Konsep Enjoyful Learning, Semarang, Indonesia [6] Chee, Yam San (2007), Embodiment, Embeddedness, and Experience: Game- Based Learning And The Construction of Identity. Research and Practice in Technology Enhanced Learning

[7]Arum, Dewi. (2007). Uji Keunggulan Alat Peraga Wayang Abjad Kontekstual dalam Pencapaian Kemampuan Baca Tulis Anak Kelompok B TK Negeri Singaraja. Jurnal Penelitian dan Pengembangan Pendidikan. Singaraja: Lembaga Penelitian Undiksha.

[8] Rozi, Fatkhur, 2009, Game Berbasis Petualangan Untuk Pembelajaran Listening Bahasa Inggris Siswa Kelas X Di Sman 1 Welahan Kabupaten Jepara, Semarang, Indonesia
[9] Jayakanthan, R. (2002). Application of Computer Games in the Field of Education. Emerald.

[10]Departemen Pendidikan Nasional Badan Penelitian Dan Pengembangan, 2007, Naskah Akademik Kajian Kebijakan 